\title{
Release of soluble vascular endothelial growth factor receptor-I (sFIt-I) during coronary artery bypass surgery
}

\author{
Yves Denizot*1, Alexandre Leguyader ${ }^{2}$, Elisabeth Cornu², Marc Laskar², \\ Isabelle Orsel ${ }^{3}$, Christelle Vincent ${ }^{1}$ and Nathalie Nathan ${ }^{3}$
}

Address: ${ }^{1}$ UMR CNRS 6101, Centre National de la Recherche Scientifique, Université de Limoges, France, ${ }^{2}$ Service de Chirurgie Thoracique et Cardiovasculaire, CHU Dupuytren, Limoges, France and '3Service d'Anesthésie Réanimation Chirurgicale, CHU Dupuytren, Limoges, France

Email: Yves Denizot* - yves.denizot@unilim.fr; Alexandre Leguyader - alexandre.leguyader@unilim.fr;

Elisabeth Cornu - elisabeth.cornu@unilim.fr; Marc Laskar - m.laskar@unilim.fr; Isabelle Orsel - isabelle.orsel@chu-limoges.fr; Christelle Vincent - cricrifab@voila.fr; Nathalie Nathan - nathan@unilim.fr

* Corresponding author

Published: 21 September 2007

Journal of Cardiothoracic Surgery 2007, 2:38 doi:10.1/86/1749-8090-2-38
Received: 4 July 2007

Accepted: 2I September 2007

This article is available from: http://www.cardiothoracicsurgery.org/content/2/l/38

(c) 2007 Denizot et al; licensee BioMed Central Ltd.

This is an Open Access article distributed under the terms of the Creative Commons Attribution License (http://creativecommons.org/licenses/by/2.0), which permits unrestricted use, distribution, and reproduction in any medium, provided the original work is properly cited.

\begin{abstract}
Background: This study was conducted to follow plasma concentrations of sFIt-I and sKDR, two soluble forms of the vascular endothelial growth factor (VEGF) receptor in patients undergoing coronary artery bypass graft (CABG) surgery with extracorporeal circulation (ECC).
\end{abstract}

Methods: Plasma samples were obtained before, during and after surgery in 15 patients scheduled to undergo CABG. Levels of sFIt-I and KDR levels were investigated using specific ELISA.

Results: A 75-fold increase of sFlt-I was found during cardiac surgery, sFlt-I levels returning to pre-operative values at the $6^{\text {th }}$ post-operative hour. In contrast sKDR levels did not change during surgery. The ECC-derived sFlt-I was functional as judge by its inhibitory effect on the VEGF mitogenic response in human umbilical vein endothelial cells (HUVECs). Kinetic experiments revealed sFIt-I release immediately after the beginning of ECC suggesting a proteolysis of its membrane form ( $\mathrm{mFIt}-\mathrm{I}$ ) rather than an elevated transcription/translation process. Flow cytometry analysis highlighted no effect of ECC on the shedding of mFlt-I on platelets and leukocytes suggesting vascular endothelial cell as a putative cell source for the ECC-derived sFlt-I.

Conclusion: sFIt-I is released during CABG with ECC. It might be suggested that sFlt-I production, by neutralizing VEGF and/or by inactivating membrane-bound Flt-I and KDR receptors, might play a role in the occurrence of post-CABG complication.

\section{Introduction}

Coronary artery bypass graft (CABG) surgery with extracorporeal circulation (ECC) is associated with an inflammatory response because, among numerous other causes, of blood contact with the artificial bypass surface, cold cardiac ischaemia and hypothermia [1-3]. Various studies have highlighted alterations in lipidic, cytokine and hae- matopoietic colony stimulating factor (CSF) networks during and after CABG surgery [4-10]. Thus, circulating levels as platelet-activating factor, leukotriene $\mathrm{B}_{4}$, thromboxane $B_{2}$, interleukin (IL)-6, IL-8, IL-10, soluble IL-1 receptors, soluble tumour necrosis factor alpha (TNF- $\alpha$ ) receptors, macrophage-CSF (M-CSF) and granulocyte-CSF (G-CSF) are altered during and after surgery and might be 
involved in the post-CABG multiple organ failure syndrome. It is now clear that these productions did not reflect an unspecific inflammatory state since levels of IL4, IL-13, leukemia inhibitory factor, GM-CSF, and soluble IL-6 receptors remain unchanged during and after cardiac surgery $[6,8,9]$.

The angiogenic network is also affected during and after CABG [10]. Among angiogenic growth factors, vascular endothelial growth factor (VEGF) fulfils a central role in the formation and function of blood vessels and during vascular healing in response, for example, to vascular trauma induced by mechanical disruption $[11,12]$. VEGF has been characterized as a heparin binding angiogenic growth factor displaying high specificity for endothelial cells. The expression of VEGF is stimulated in response to hypoxia and by a wide range of inflammatory cytokines. In vivo VEGF induces angiogenesis as well as permeabilisation of blood vessels and play central role in the regulation of vasculogenesis [13]. VEGF receptor (VEGFR) family consists of three members Flt-1 (VEGFR-1), KDR (VEGFR-2) and Flt-4 (VEGFR-3), all of which belong to the receptor tyrosine kinase superfamily [13]. Flt-1 and KDR exhibited high affinity for VEGF. Flt- 4 is closely related in structure to the products of the Flt 1 and KDR genes. However, VEGF did not show specific binding for Flt-4 and its expression is restricted to developing lymphatic vessels. Soluble forms of the Flt-1 (sFlt-1) and KDR (sKDR) are found in human plasma [13]. Studies highlighted that soluble form of receptors are capable of sequestering ligand and preventing signal transduction. Excessive placental sFlt-1 production, by neutralizing VEGF, may play a causal role in the pathogenesis of the maternal preeclampsia [14]. Studies reported an association between coronary artery disease or myocardial infarction and elevated circulating levels of VEGF $[15,16]$. Of interest, reduced circulating levels of sFlt- 1 were found in these patients suggesting lost of the endogenous compensatory anti-inflammatory mechanism induced by sFlt-1. Strengthening this hypothesis, sFlt-1 was recently reported to attenuate sepsis morbidity and mortality in an experimental mouse model by improving both cardiac and lung functions as compared with untreated animals [17]. Whether circulating VEGF levels are affected after CABG $[10,18,19]$, no data are currently available concerning values of its soluble receptors. This study was conducted to elucidate whether sFlt-1 and sKDR were released during CABG with ECC.

\section{Patients and methods}

The investigation conforms with the principles outlined in the Declaration of Helsinki. Fifteen patients scheduled to undergo CABG were included in this study. All patients had a preoperative ejection fraction above $40 \%$. Anaesthesia was induced and maintained with titrated doses of fen- tanyl and flunitrazepam. Muscular relaxation was achieved with pancuronium $(0.1 \mathrm{mg} / \mathrm{kg})$. Membrane oxygenators were used. The blood was harvested from the surgical field and from the cell saver at the end of ECC and reinfused to all patients. All patients received high doses of aprotinin. Plasma samples were collected from the radial artery catheter before vascular cannulation and after opening the chest $\left(T_{0}\right)$, at the end of ECC just before $\left(T_{1}\right)$ and after cross clamp release $\left(\mathrm{T}_{2}\right)$, after weaning from ECC $\left(\mathrm{T}_{3}\right)$, at the $6^{\text {th }}\left(\mathrm{T}_{4}\right)$ and $24^{\text {th }}$ post-operative hour $\left(\mathrm{T}_{5}\right)$. All patients had uneventful surgery. Plasma samples were collected between January 1995 and December 1996 [4] and were stored at $-80^{\circ} \mathrm{C}$ until sFlt 1 and sKDR assays.

In another set of experiments, an in order to test more precisely the kinetic of sFlt-1 release, blood samples were harvested from a new set of 10 patients before ECC $\left(\mathrm{T}_{0}\right)$, immediately at the beginning of ECC before aortic cross clamp $\left(\mathrm{T}_{1^{\prime}}\right)$ or after aortic cross clamp $\left(\mathrm{T}_{2^{\prime}}\right)$. Leukocytes and platelets were counted in a haemocytometer. Blood mononuclear cells were recovered on a Ficoll gradient in order to extract their RNA contents. Aliquots of blood were immediately used for flow cytometry analysis of membrane Flt-1 (mFlt-1) on platelets, monocytes, lymphocytes and granulocytes. Plasma samples were stored at $-80^{\circ} \mathrm{C}$ until sFlt- 1 and sKDR assays.

A decrease of plasma protein contents was observed during and after CABG surgery [1]. In order to avoid the influence of haemodilution during bypass, plasma sFlt-1 and sKDR levels were expressed by pg per mg of total plasma protein contents $(\mathrm{pg} / \mathrm{mg})$ measured at the simultaneous times. The proteinemia was determined by the BCA Protein Assay Reagent (Pierce, Rockford, IL). Plasma sFlt-1 and sKDR levels were measured with commercially ELISA kits (R\&D Systems, Abingdon, UK). Biological results were expressed by $\mathrm{pg} / \mathrm{mg}$ of protein measured at the simultaneous times. The sensitivity of the assays enables the detection of levels as low as $20 \mathrm{pg} / \mathrm{ml}$ and $30 \mathrm{pg} / \mathrm{ml}$ for sFlt-1 and sKDR, respectively. Results are expressed as mean \pm SEM.

Blood mononuclear cells were separated on a Ficoll gradient $(400 \times \mathrm{g}, 20 \mathrm{~min})$ and washed two times with Hanks' balanced salts solution (HBSS). Total RNA was extracted with Tri Reagent ${ }^{\circledast}$ (Ambion, Austin, TX). Reverse transcription (RT) was performed with $2.5 \mu \mathrm{g}$ total RNA with the SuperScript reverse transcriptase (Invitrogen, Cergy Pontoise, France). Polymerase chain reaction (PCR) experiments for sFlt- 1 transcripts were carried out with a sense primer 5'-TGTCAATGTGAAACCCCAGA-3' and an antisense primer 5'-GTCACACCTTGCTTCGG AAT-3' which amplify a 175 bp fragment of the human sFlt-1 gene. Amplification of glyceraldehyde-3-phosphate dehydrogenase (GAPDH) was performed to confirm the integrity of 
RNA. The GAPDH sense and anti-sense primers were 5'GGCTGAGAACGGGAAGC TTG-3' and 5'-GGATGATGTTCTGGAGAGCC-3', amplifying a 439 bp fragment. cDNA was denatured $180 \mathrm{sec}$ at $94^{\circ} \mathrm{C}$, and then submitted to 40 cycles consisting in $94^{\circ} \mathrm{C} / 60 \mathrm{sec}, 58^{\circ} \mathrm{C}$ or $60^{\circ} \mathrm{C}$ (for sVEGFR-1 and GAPDH, respectively)/60 sec and $72{ }^{\circ} \mathrm{C} / 75$ sec. Products were then analysed on an agarose gel stained with ethidium bromide. sFlt-1 PCR products were cloned in Topo $^{\mathrm{TM}}$ cloning kit (Invitrogen) and sequenced by the dideoxynucleotide method on an ABI Prism 310 DNA genetic analyzer (Applied Biosystems, Foster City, CA).

The presence of mFlt-1 was tested by direct immunofluorescence staining of whole blood (acid-citrate-dextroseanticoagulated) using fluorochrome-conjugated antibodies. Briefly $50 \mu \mathrm{l}$ of whole blood were incubated with 20 $\mu \mathrm{l}$ of mouse IgG $_{1}$ anti-human Flt-1 conjugated with phycoerythrin (PE) or irrelevant mouse IgG $_{1}$ PE-conjugated isotype control ( $R \& D$ systems, Minneapolis, $M N$ ) for 30 min at $4^{\circ} \mathrm{C}$. Red blood cells were lysed, washed in PBS buffer, and samples were incubated with anti-CD45 PC7 labelled antibodies. After washing, cells were then submitted to flow cytometric analysis (XL II, Coulter, Margency, France). Platelets, lymphocytes, monocytes and granulocytes were identified based on the typical morphology in the forward scatter/side scatter cytogram and with the CD45 labelling.

Human umbilical vein endothelial cells (HUVECs) were purchased from Promo Cell (Heidelberg, Germany). HUVECs were grown in the media provided by the vendor and cultures were routinely used between passages 4 and 7 . HUVECs $\left(2 \times 10^{3}\right.$ cells $)$ in $100 \mu$ l of growth media were plated into 96 -well plates and cultured for 3 days at $37^{\circ} \mathrm{C}$ in $5 \% \mathrm{CO}_{2}$ in air. HUVECs were cultured in the presence or absence of $10 \mathrm{ng}$ VEGF (PeproTech, London, UK), 10 $\mu$ l of plasma collected during ECC $\left(\mathrm{T}_{2}\right)$ and/or $0.25 \mu \mathrm{g}$ rabbit anti-soluble Flt-1 (Zymed Laboratories, San Francisco, CA). Cell proliferation (in sixplicates) was measured by a colorimetric method using MTS (Promega, Madison, WI). The MTS tetrazolium compound is bioreduced by cells into a colored formazan product that is soluble in tissue culture medium. This conversion is accomplished by NADPH or NADH produced by dehydrogenase enzymes in metabolically active cells. In some experiments the number of cultured cells (in quadruplicate) was directly evaluated using a haemocytometer.

Results are expressed as mean \pm SEM. Statistical analysis was done using Mann-Whitney U-test. A p $<0.05$ was considered significant.

\section{Results}

Initial concentrations of plasma VEGF of these patients were evaluated at $3 \mathrm{pg} / \mathrm{mg}$ [10]. As shown in Figure 1A, a
A

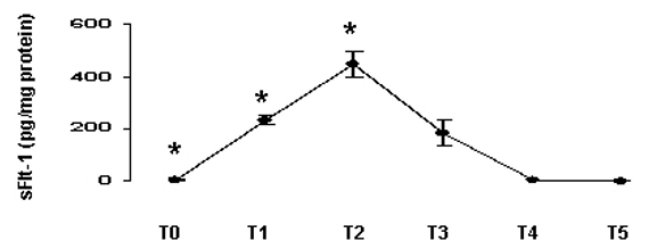

$\mathbf{B}$

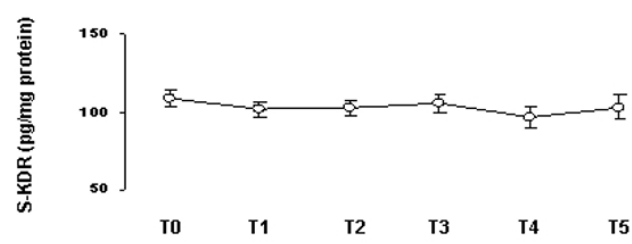

C

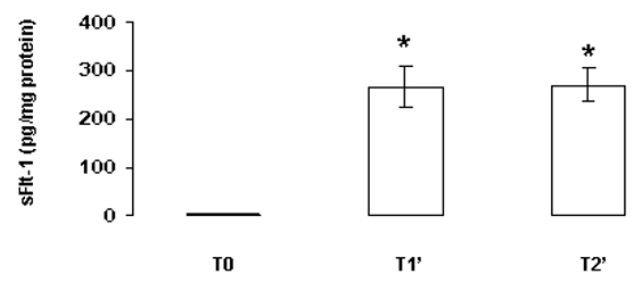

Figure I

Plasma sFIt I and sKDR levels during and after cardiopulmonary bypass graft surgery. A: Plasma sFlt-I values are expressed in pg per $\mathrm{mg}$ protein. T0: before vascular cannulation and after opening the chest; $\mathrm{T}_{1}$ : during extracorporeal circulation (ECC); $\mathrm{T}_{2}$ : at the end of ECC before cross clamp release; $\mathrm{T}_{3}$ : after cross clamp release; $\mathrm{T} 4$ : the 6 th postoperative hour; T5: the 24th post-operative hour. Mean \pm SEM of I 5 patients. *p $<0.001$ as compared with TO (MannWhitney U-test). B: Plasma sKDR levels are expressed in pg/ $\mathrm{mg}$ protein. Same blood sampling time than in A. Mean \pm SEM of 15 patients. ${ }^{*} p<0.001$ as compared with T0 (Mann-Whitney U-test). No statistical differences were observed (MannWhitney U-test). C: Plasma sFlt-I values at the beginning of ECC. TO: before vascular cannulation and after opening the chest; $\mathrm{T}_{1}$ : before cross clamp; $\mathrm{T}_{2}$ : after cross clamp. Mean \pm SEM of 10 patients. ${ }^{*} p=0.0002$ as compared with TO (MannWhitney U-test).

75-fold increase of plasma sFlt-1 concentrations was found during CABG surgery. Levels increased significantly $(\mathrm{p}=0.0001)$ during ECC $(234.2 \pm 16.2 \mathrm{pg} / \mathrm{mg})$, reached maximum values at the end of ECC before cross clamp release $(446.0 \pm 49.3 \mathrm{pg} / \mathrm{mg})$ and returned to pre-operative values $(5.9 \pm 2.7 \mathrm{pg} / \mathrm{mg})$ at the $6^{\text {th }}$ post-operative hour $(5.1 \pm 0.8 \mathrm{pg} / \mathrm{mg})$. Raw data of plasma sFlt-1 levels were $301.6 \pm 135.6 \mathrm{pg} / \mathrm{ml}$ and $14915.0 \pm 1629.2 \mathrm{pg} / \mathrm{ml}$ before ECC $\left(\mathrm{T}_{0}\right)$ and at the end of ECC $\left(\mathrm{T}_{2}\right)$, respectively. In con- 
trast to sFlt-1, plasma sKDR levels did not significantly (p $>0.2$ ) change during and after CABG surgery (Fig. 1B). As shown in Figure 1C, sFlt-1 levels significantly ( $p=0.0002)$ increased immediately after the beginning of ECC.

We then investigated if white blood cells might be putative cellular sources for the ECC-derived sFlt-1 synthesis. In a first set of experiments sFlt- 1 transcripts were evaluated in blood mononuclear cells of patients before and during ECC. PCR experiments did not reveal differences for sFlt-1 transcript levels before and after initiation of ECC (Figure 2, upper panel). The release of sFlt-1 was recently reported through proteolysis of its membrane form [20]. In a second set of experiments we, thus, evaluated the effect of ECC on mFlt-1 expression on circulating blood cell types (i.e; monocytes, lymphocytes, granulocytes and platelets). As shown in Figure 2A (lower panel), forward scatter and side scatter were used to identify platelets and leukocytes. Figure 2B illustrates the gates used to characterize lymphocytes, monocytes and granulocytes among CD45+ cells. ECC had no effect on the basal expression of mFlt-1 on granulocytes, platelets, lymphocytes and monocytes (Figures 2C, 2D, 2E and 2F, respectively).

sFlt-1 was released during ECC. We then investigated the activity of the ECC-derived sFlt-1 on the VEGF mitogenic response in HUVECs by using a colorimetric method. As shown in Figure 3A, ECC-derived sFlt-1 markedly inhibited the VEGF mitogenic response in HUVECs; the effect being abolished by the use of anti-sFlt-1 antibodies. Cell counts (Figure 3B) confirmed the effect of the ECCderived sFlt-1 on the growth of VEGF-stimulated HUVECs.

\section{Discussion}

VEGF was first characterized as a potent endothelial growth factor and stimulator of endothelial permeability. Studies highlighted that sFlt-1 is capable of sequestering VEGF and preventing signal transduction [13]. Moreover, sFlt-1 can act as an endogenous VEGF inhibitor not only by sequestering VEGF but also by binding and inactivating membrane-bound Flt-1 and KDR receptors through a mechanism involving receptor homodimerisation or heterodimerisation [21]. The presence of sFlt-1 in serum and plasma of healthy donors strongly suggest that sFlt-1 might have an important function in the fine regulation of VEGF mediated activities in vivo. Beside its effect on endothelial permeability, VEGF is also reported to exhibit several pro-inflammatory and procoagulant activities [2224]. Data have demonstrated elevated VEGF levels following CABG surgery $[10,18,19]$, suggesting that VEGF is a component of the inflammatory network after open heart surgery. In this study we showed a dramatic (up to 75fold) increase of circulating sFlt-1 levels during ECC. In contrast sKDR levels were unchanged strengthening the idea that sFlt- 1 release is not only the consequence of an unspecific release in response to cardiac surgery. The ECCderived sFlt-1 is functional as judged by its effect in the VEGF-induced proliferation of HUVECs. The cell source and the mechanism of these elevated levels of sFlt-1 remain speculative. During the past decade sFlt- 1 was reported to be generated by an alternative splicing of the mFlt-1 transcript [13]. In our study, sFlt-1 levels peaked during ECC returning to pre-operative levels at the $6^{\text {th }}$ post operative hours. This rapid kinetics of production does not fit well with an elevated transcription, translation and/or maturation process. Two hypothesises might, thus, be suggested. The first one is the presence of pre-existing intracellular pool of sFlt-1 that might be released upon cell stimulation. The presence of intracellular pool of soluble Toll-like receptors and tumour necrosis factor alpha (TNF- $\alpha$ ) receptors have been already described $[25,26]$. Of interest, the presence of KDR intracellular pools have been recently reported in endothelial cells [27], suggesting the putative existence of similar Flt- 1 ones. The second hypothesis is a proteolysis process. Numerous transmembrane cell surface proteins exist as soluble forms suggesting that their cleavage and release from the cell surface represent a rapid and efficient post-translational regulatory mechanism. The proteolytic solubilisation of the ligand-binding cytokine receptor ectodomains not only renders cells insensitive toward cytokine effects. The capacity of soluble receptor forms to bind their ligands may prevent the cytokine binding to cell-bound receptors. Soluble receptors for leukocyte and endothelial cell activation molecules (Fas ligand, CD40, CD93), for cytokine receptors (IL-1, IL-2, IL-6, TNF- $\alpha$ ), for adhesion and locomotion molecules (CD44, CXCL16, ICAM-1, VCAM-1), for cell-to-cell adhesion molecules involved in endothelial diapedesis (PECAM-1, VE-cadherin), and for growth factors (bFGF, PDGF) are released by proteolysis by a wide array of enzymatic activities including neutrophil-derived serine proteases, secretases (sheddases), metalloproteases and ADAMs [28-30]. In our study, flow cytometry analysis did not highlight any effect of ECC on mFlt-1 levels on white blood cells and platelets. Recently a $\gamma$-secretasedependent Flt-1 intramembrane proteolysis was found in vascular endothelial cells reporting, for the first time, a shedding contribution for the sFlt-1 receptor [20]. The ectodomain shedding of mFlt-1 on vascular endothelial cells might, thus, be a putative mechanism explaining the rapid release of sFlt- 1 in blood during ECC. Of interest serine proteases, metalloproteases and ADAM are activated during cardiopulmonary bypass [31-33].

\section{Conclusion}

sFlt-1 is released during CABG with ECC. The precise mechanisms of this sFlt-1 production remain to be elucidated. The existence of pre-existing intracellular endothe- 

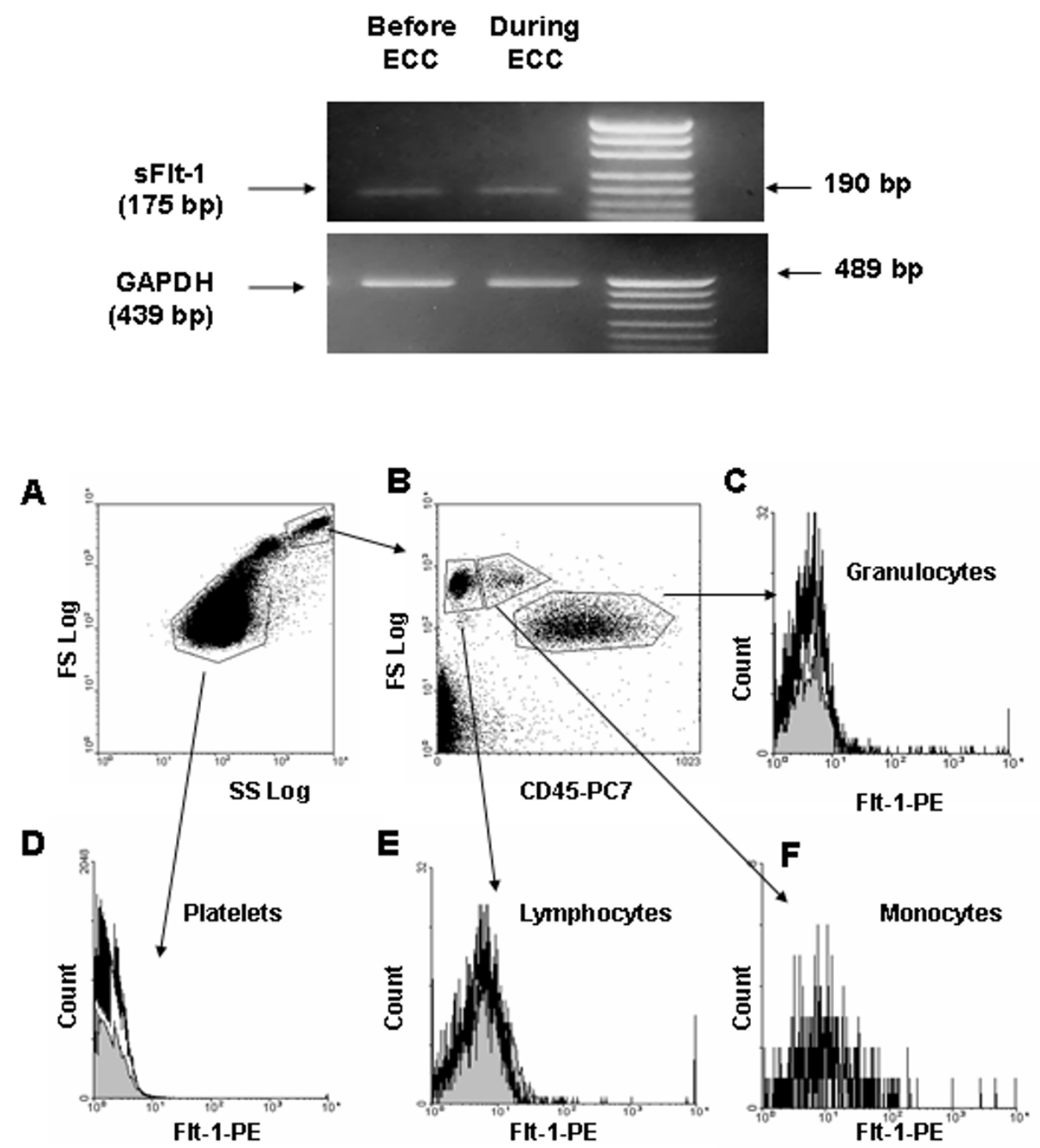

Figure 2

RT-PCR analysis of sFlt-I transcripts and mFlt-I on blood mononuclear cells before and during ECC. A: PCR experiments were carried out to amplify a 175 bp fragment of the human sFlt-I receptor. GAPDH amplification (a 439 bp fragment) was performed to highlight the integrity of blood mononuclear cell mRNA. PCR products were analysed on a I.2\% agarose gel. Sizes of PCR products and DNA ladder are indicated by arrows. One representative experiment out of three is shown. B: Blood samples were collected before and during ECC. Forward scatter (FS) and side scatter (SS) were used to identify platelets and leukocytes (A). CD45 expression was used to separate lymphocytes, monocytes and granulocytes (B). Flow cytometry revealed no significant effect of ECC on mFlt-I expression on platelets (C), lymphocytes (D), monocytes (E) and granulmocytes (F). The solid line represents blood cells before ECC staining with Flt-I-PE antibodies. The shaded area represents blood cells during ECC staining with Flt-I-PE antibodies. One experiment representative of 3 is shown. 


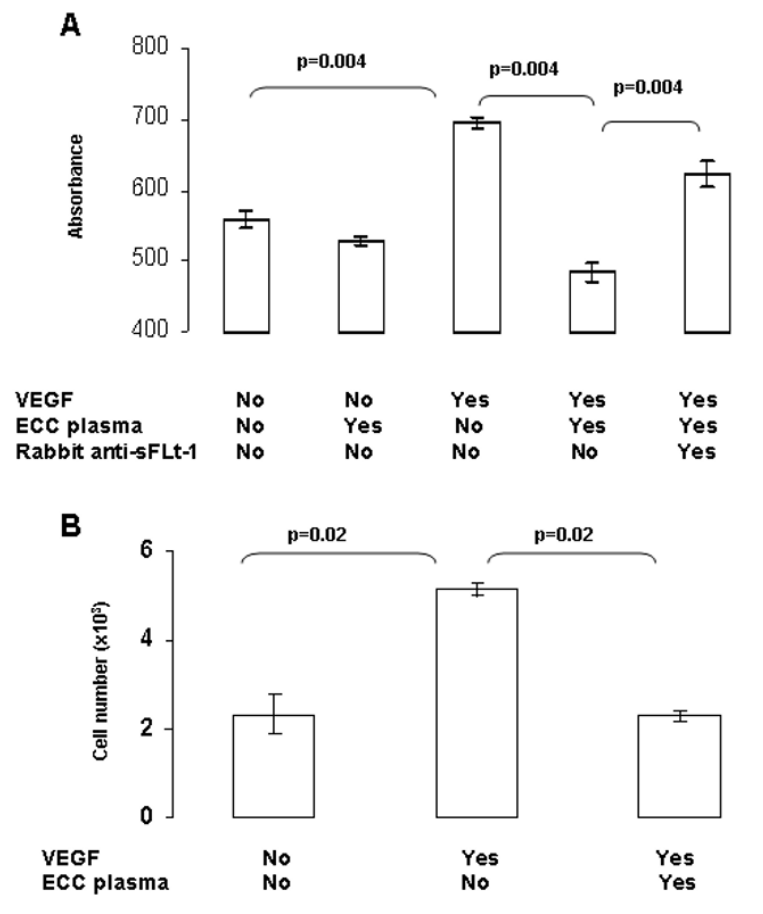

\section{Figure 3}

Effect of ECC-derived sFIt-I on HUVEC proliferation. HUVECs $\left(2 \times 10^{3}\right.$ cells $)$ were cultured alone or in the presence of $10 \mathrm{ng}$ VEGF, $10 \mu \mathrm{l}$ of plasma collected at $\mathrm{T}_{2}$ during ECC and/or $0.25 \mu \mathrm{g}$ rabbit anti-soluble Flt-I. A: Cell proliferation (in sixplicates) was measured by a colorimetric method. One representative experiment out of 3 is shown. B: Cell number (in quadruplicate) was determined by direct cell counts. One representative experiment out of 2 is shown. Statistical differences were made using the Mann-Whitney Utest.

lial pool of sFlt-1 that might be released upon cell stimulation or the shedding of endothelial mFlt-1 may be two putative mechanisms. At this time the physiologic meaning of these elevated sFlt-1 levels remains speculative. It might be suggested that sFlt-1 production, by neutralizing VEGF and/or by inactivating membrane-bound Flt- 1 and KDR receptors, might play a role in the occurrence of post-CABG complications. Investigation of sFlt-1 levels in patients with post-CABG complications would be of interest to test this hypothesis. If the release of sFlt- 1 is benefit to reduce post-CABG complications sFlt- 1 might became a potential target for preoperative intervention in the form of sFlt-1 pharmacologic therapy to prevent or ameliorate some postoperative complications of CABG by interfering very early in the VEGF-induced inflammatory cascade rather than later when the number of proinflammatory molecules and their associated damages are greater. Animal models have still highlighted the interest of sFlt- 1 administration in order to reduce disease severity in experimental inflammatory diseases and sepsis $[17,34,35]$. Finally, the activation of VEGFR-1 is essential for recruitment of adult stem cells. Endothelial progenitors are mobilized into the circulation after CABG [36]. During CABG it is possible that the increase concentration of sFlt-1 could affect the recruitment of endothelial cell progenitors with adverse effects on cardiac physiology after bypass procedure. Strengthening this hypothesis decrease and dysfunction of endothelial progenitor cells have been found in umbilical cord blood with maternal pre-eclampsia; these alterations being associated with the increased sFlt-1 levels in the umbilical cord blood [37].

\section{Abbreviations}

CABG - coronary artery bypass graft, ECC - extracorporeal circulation, HUVECs - human umbilical vein endothelial cells, VEGF - vascular endothelial growth factor

\section{Competing interests}

The author(s) declare that they have no competing interests.

\section{Authors' contributions}

$\mathrm{AL}, \mathrm{EC}, \mathrm{ML}, \mathrm{IO}$ and NN were the surgical and anaesthesia teams and carried out the preoperative clinical and analytical data collection, carried out blood samples and actively participate to the study design, data interpretation and manuscript writing.

YD and CV carried out the determination of sFlt- 1 and sKDR values, RT-PCR experiments, flow cytometry analysis and interpretations and actively participate to manuscript writing.

All authors read and approved the final manuscript.

\section{References}

I. Larmann J, Theilmeier G: Inflammatory response to cardiac surgery: cardiopulmonary bypass versus non-cardiopulmonary bypass surgery. Best Pract Res Clin Anaesthesiol 2004, 18:425-438.

2. Weigand MA, Hörner C, Bardenheuer HJ, Bouchon A: The systemic inflammatory response syndrome. Best Pract Res Clin Anaesthesiol 2004, I 8:455-475.

3. Paparella D, Brister SJ, Buchanan MR: Coagulation disorders of cardiopulmonary bypass: a review. Int Care Med 2004, 30:1873-|88|.

4. Nathan N, Denizot $Y$, Cornu E, Jauberteau MO, Chauveau C, Feiss P: Cytokine and lipid mediator blood concentrations after coronary artery surgery. Anesth Analg 1997, 85: I240-1246.

5. Kawamura T, Wakusawa R, Inada K: Interleukin-10 and interleukin-I receptor antagonists increase during cardiac surgery. Can J Anaesth 1997, 44:38-42.

6. Nathan N, Preux PM, Feiss P, Denizot Y: Plasma interleukin-4, interleukin- 10 , and interleukin- 13 concentrations and com- 
plications after coronary artery bypass graft surgery. J Cardiothorac Vasc Anesth 2000, 14:156-160.

7. McBride WT, Armstrong MA, Gilliland H, McMurray TJ: The balance of pro and anti-inflammatory cytokines in plasma and bronchoalveolar lavage (BAL) at paediatric cardiac surgery. Cytokine 1996, 8:724-729.

8. Denizot $\mathrm{Y}$, Karoutsos $\mathrm{S}$, Nathan N: Differential alterations in plasma colony-stimulating factor concentrations after coronary artery bypass graft surgery with extracorporeal circulation. Cytokine 200I, 13:3|4-316.

9. Denizot V, Lorgeot V, Cornu E, Nathan N: Plasma leukemia inhibitory factor, interleukin-6 and soluble interleukin-6 receptor levels during cardiopulmonary bypass with extracorporeal circulation. Cytokine 1998, 10:303-306.

10. Denizot Y, Guglielmi L, Cornu E, Nathan N: Alterations in plasma angiogenic growth factor concentrations after coronary artery bypass graft surgery: relationships with post-operative complications. Cytokine 2003, 24:7-12.

II. Smith SK: Angiogenesis, vascular endothelial growth factor and the endometrium. Hum Reprod Update 1998, 4:509-5I9.

12. Norrby K: Mast cells and angiogenesis. APMIS 2002, I I 0:355-37I.

13. Neufeld G, Cohen T, Gengrinovitch S, Poltorak Z: Vascular endothelial growth factor (VEGF) and its receptors. FASEB J 1999, 13:9-22.

14. Levine RJ, Karumanchi SA: Circulating angiogenic factors in preeclampsia. Clin Obstet Gynecol 2005, 48:372-386.

15. Chung NAY, Lydakis C, Belgore F, Blann AD, Lip GYH: Angiogenesis in myocardial infarction. An acute or chronic process? Eur Heart J 2002, 23: 1604-1608.

16. Chung NA, Lydakis C, Belgore F, Li-Saw-Hee FL, Blann AD, Lip GYH: Angiogenesis, thrombogenesis, endothelial dysfunction and angiographic severity of coronary artery disease. Heart 2003, 89: $14 \mid 1-1415$

17. Yano K, Liaw PC, Mullington JM, Shih SC, Okada H, Bodyak N, Kang PM, Toltl L, Belikoff B, Buras J, Simms BT, Mizgerd JP, Carmeliet P, Karumanchi SA, Aird WC: Vacular endothelial growth factor is an important determinant of sepsis morbidity and mortality. J Exp Med 2006, 203:| 447-| 458.

18. Burton PBJ, Owen VJ, Hafizi S, Barton PJR, Carr-White G, Koh T, De Souza A, Yacoub MH, Pepper JR: Vascular endothelial growth factor release following coronary artery bypass surgery: extracorporeal circulation versus "beating heart" surgery. Eur Heart J 2000, 21: 1708-1713.

19. Cotton JM, Mathur A, Hong Y, Brown AS, Martin JF, Erusalimsky JD: Acute rise of circulating vascular endothelial growth factor$A$ in patients with coronary artery disease following cardiothoracic surgery. Eur Heart J 2002, 23:953-959.

20. Cai J, Jiang WG, Grant MB, Boulton M: Pigment epitheliumderived factor inhibits angiogenesis via regulated intracellular proteolysis of vascular endothelial growth factor receptor I. J Biol Chem 2006, 28 I:3604-36I3.

21. Kendall RL, Wang G, Thomas KA: Identification of a natural soluble form of the vascular endothelium growth factor receptor, FLT-I, and its heterodimerisation with KDR. Biochem Biophys Res Commun 1996, 226:324-328.

22. Koutroubakis IE, Tsiolakidou G, Karmiris K, Kouroumalis EA: Role of angiogenesis in inflammatory bowel disease. Inflamm Bowel Dis 2006, I 2:5I5-523.

23. Kuenen BC, Levi M, Meijers JCM, Kakkar AK, van Hinsbergh VWM, Kostense PJ, Pinedo HM, Koekman K: Analysis of coagulation cascade and endothelial cell activation during inhibition of vascular endothelial growth factor/vascular endothelial growth factor receptor pathway in cancer patients. Artherioscler Thromb Vasc Biol 2002, 22: I500-I 505.

24. Reinders MEJ, Sho M, Izawa A, Wang P, Mukhopadhyay D, Koss KE, Geehan CS, Luster AD, Sayegh MH, Briscoe DM: Proinflammatory functions of vascular endothelial growth factor in alloimmunity. J Clin Invest 2003, I I 2:1655-1665.

25. LeBouder E, Rey-Nores JE, Rushmere NK, Grigorov M, Lawn SD, Affolter M, Griffin GE, Ferrara P, Schiffrin EJ, Morgan BP, Labéta MO: Soluble forms of toll-like receptor (TLR)2 capable of modulating TLR2 signaling are present in human plasma and breast milk. J Immunol 2003, I 7 1:6680-6689.

26. Wang J, Al-Lamki RS, Zhang H, Kirkiles-Smith N, Gaeta ML, Thiru S, Pober JS, Bradley JR: Histamine antagonizes tumor necrosis factor (TNF) signalling by stimulating TNF receptor shedding from the cell surface and golgi storage pool. J Biol Chem 2003, 278:2175I-21760.

27. Gampel A, Moss L, Jones MC, Bruton V, Norman JC, Mellor H: VEGF regulates the mobilisation of VEGFR-2/KDR from an intracellular endothelial storage compartment. Blood 2006, 108:2624-2631.

28. Bank U, Ansorge S: More than destructive: neutrophil-derived serine proteases in cytokine bioactivity control. J Leuk Biol 2001, 69:197-206.

29. Hooper NM, Karran EH, Turner AJ: Membrane protein secretases. Biochem J 1997, 32 I:265-279.

30. Steals D, Courtneidge SA: The ADAMs family of metalloproteases: multidomain proteins with multiple functions. Genes Dev 2003, 17:7-30.

31. Lin TC, Li CY, Tsai CS, Ku CH, Wu CT, Wong CS, Ho ST: Neutrophil-mediated secretion and activation of matrix metalloproteinase-9 during cardiac surgery with cardiopulmonary bypass. Anesth Analg 2005, 100:1554-1560.

32. Kameda K, Matsunaga T, Abe N, Fujiwara T, Hanada H, Fukui $K$ Fukuda I, Osanai T, Okumura K: Increased pericardial fluid level of matrix metalloprotease- 9 activity in patients with acute myocardial infarction: possible role in the development of cardiac rupture. Circ J 2006, 70:673-678.

33. Mannucci PM, Parolari A, Canciani MT, Alemanni F, Camera M: Opposite changes of ADAMTS- 13 and von Willebrand factor after cardiac surgery. J Thromb Haemost 2005, 3:397-399.

34. Hamade N, Kuwano K, Yamada M, Hagimoto N, Hiasa K, Egashira K, Nakashima N, Maeyama T, Yoshimi M, Nakanishi Y: Anti-vascular endothelial growth factor gene therapy attenuates lung injury and fibrosis in mice. J Immunol 2005, I 75: | 224-I23I.

35. Miotla J, Maciewicz R, Kendrew J, Feldmann M, Paleolog E: Treatment with soluble VEGF receptor reduces disease severity in murine collagen-induced arthritis. Lab Invest 2000, 80: I I95-1205.

36. Mieno S, Ramlawi B, Boodhwani M, Clements RT, Minamimure $\mathrm{K}$, Maki T, Xu SH, Bianchi C, Li J, Sellke FW: Role of stromal-derived factor-I alpha in the induction of circulating CD34+CXCR4+ progenitor cells after cardiac surgery. Circulation 2006, II4:1182-1192.

37. Xia L, Zhou XP, Zhu JH, Xie XD, Zhang H, Wang XX, Chen JZ, Jian $S$ : Decrease and dysfunction of endothelial progenitor cells in umbilical cord blood with maternal pre-eclampsia. J Obstet Gynaecol Res 2007, 33:465-474.

Publish with Bio Med Central and every scientist can read your work free of charge

"BioMed Central will be the most significant development for disseminating the results of biomedical research in our lifetime. "

Sir Paul Nurse, Cancer Research UK

Your research papers will be:

- available free of charge to the entire biomedical community

- peer reviewed and published immediately upon acceptance

- cited in PubMed and archived on PubMed Central

- yours - you keep the copyright 